Jurnal Ekonomi dan Industri

e-ISSN: 2656-3169

Volume 22, No.2, Mei-Agustus 2021

p- ISSN: 0853-5248

\title{
PENGARUH PELAYANAN MUDLARABAH TERHADAP TINGKAT KEPUASAN ANGGOTA KOPERASI DAN MASYARAKAT KOPERASI BHAKTI PERTIWI ABADI JAKARTA TIMUR
}

\author{
Abdullah Fathoni *) \\ *) Dosen Program Sturi Manajeen FE UNKRIS \\ Alamat: Kampus UNKRIS, Jatiwaringin Jakarta Timur \\ Email: fathoni44@yahoo.co.id
}

\begin{abstract}
Syaria economy is part of global industry. Every country in the world has a different background in establishing the country, for instances different values, differences in natural resources, and others. For this reason, the approach used to elaborate each of the problems will be different because different country has different methods to face the economic globalization. Compromising the rationality of the cooperative economic thoughts and the sharia economics is a method to find a new balance point between local wisdom, national ideals, and the values of the Indonesian nation in responding to economic globalization. There are two approaches used in this paper. Firstly, "field study" or direct observation on the object of research which are the cooperatives. Secondly, approaching to the sharia economic agents and the academics, termed as "librarian study", in which to conduct a literature review with several book references in the author's personal library. The systematics used in this study are as follows; first, to formulate an academic study of the problems surrounding Indonesia's economic development and to formulate the contemporary economic challenges. Second, bring the formulation result to be a point for discussion in campus at undergraduate and postgraduate level. Third, bring the discussions result as a point for discussion and study among experts in cooperative economics and sharia economics. Fourth, find the references against the results of the study's third phase according to the literature study. Fifth, writing scripts or papers with various academic empirical studies. From the results of the study above, it can be concluded that Indonesian must formulate their own future steps to face economic globalization, based on their own national identity as formulated in the values contained in Pancasila and Article 33 of the 1945 Constitution.
\end{abstract}

Keyword: Syaria economy, economic globalization

\section{PENDAHULUAN}

Ekonomi syariah merupakan bagian dari globalisasi ekonomi yang termasuk di dalamnya adalah koperasi syariah yang dalam hal ini adalah Koperasi Bhakti Pertiwi Abadi Jakarta Timur yang menggunakan akad "Mudlarabah". Globalisasi ekonomi sebagai dampak dari kemajuan teknologi, terutama teknologi industri dan teknologi informasi merupakan suatu kenyataan yang harus dilalui oleh para pelaku ekonomi baik pada skala internasional, regional atau nasional dengan sikap terpaksa atau sukarela. Kondisi ini telah mengharuskan perangkat eksekutif, legislative dan yudikatif untuk segera menyesuaikan dengan proses dinamisasi dalam kehidupan berbangsa dan bernegara agar tidak tertinggal dari negaranegara lain guna mempertahankan atau meningkatkan kesejahteraan masyarakat.

Tata kelola ekonomi secara adil dan proporsional di era globalisasi sangat diharapkan sehingga semua negara baik negara maju, negara sedang berkembang dan negara miskin mendapatkan manfaat secara proporsional. Akan tetapi harapan positif dampak globalisasi 
ini dikritisi oleh pakar ekonomi "Stiglitz" (penerima penghargaan hadiah Nobel bidang ekonomi tahun 2001 dan Ketua Dewan Penasihat Ekonomi dalam pemerintahan Presiden "Bill Clinton). Globalisasi merupakan alur sistem ekonomi yang berkembang saat ini yang harus dihadapi oleh negara sedang berkembang, terlepas suka atau tidak suka kebijakan ekonomi secara simultan harus berorientasi pada peningkatan kesejahteraan masyarakat secara menyeluruh dengan meniadakan ketidakseimbangan secara ekonomi antara negara maju dan negara sedang berkembang. Tragedi kemanusiaan dapat terjadi di negara sedang berkembang dan negara miskin ketika jarak kemakmuran secara ekonomi antara negara maju dan negara sedang berkembang semakin jauh, sehingga secara tidak langsung dapat dikatakan bahwa dampak positif globalisasi banyak dinikmati oleh negara maju dengan dua alasan, yaitu negara maju pemegang modal dan sekaligus pemegang kendali regulasi.

Menurut Stiglitz (2007), NAFTA atau "North American Free Trade Agreement" pada tahun 1994 yang membentuk kerjasama ekonomi antara Meksiko, Amerika Serikat dan Kanada. Implikasi dari perjanjian tersebut banyak membawa keberuntungan besar bagi Amerika Serikat, pendapatan perkapita Amerika Serikat enam kali lipat dibandingkan dengan Meksiko, dan terjadi mutasi atau perpindahan tenaga kerja produktif warga negara Meksiko sekitar 10 juta penduduk ke Amerika Serikat, baik melalui jalan resmi atau imigran gelap. Pada posisi ini Amerika Serikat memegang kendali secara sempurna terhadap tenaga kerja Meksiko karena pemegang modal dan regulasi . Untuk itu sangat diperlukan tata kelola ekonomi secara adil dan proporsional sebagai jawaban atas globalisasi ekonomi.

Menurut Azra (2005), "Blessin in Disguise" atau rahmat terselubung adalah suatu bentuk hikmah dibalik kejadian bencana, artinya pada setiap musibah yang menimpa suatu negara atau pada komunitas tertentu terkandung nilai positif yang Tuhan tempatkan dibalik kejadian tersebut.

Respon positif-negatif pada era globalisasi ekonomi menuntut adanya interaksi proporsional pada tata kelola ekonomi di setiap negara sebagai respon kearifan lokal. Pada posisi ini sangat penting untuk dikaji secara akademis pemikiran ekonomi koperasi dan ekonomi syariah dalam rangka merespon pemikiran tata kelola ekonomi yang memberikan kebebasan secara luas dalam bentuk pasar bebas. Respon tersebut dimaksudkan untuk menjaga keseimbangan antara globalisasi dan kearifan lokal dengan harapan membawa dampak positif kemakmuran bersama. Pemikiran ekonomi masa depan harus mengakomodiasikan kepentingan negara sedang berkembang. Untuk itu peran aktif pemerintah dan lembaga perekonomian internasional seperti Bank Dunia dan IMF harus berperan membuat regulasi untuk menjaga keseimbangan kepentingan antara negara maju dan negara sedang berkembang, sehingga hubungan keduanya saling menguntungkan atau hubungan "mutualisma".

\section{LANDASAN TEORI}

Ada istilah yang berkembang di masyarakat secara luas terutama di kalangan akademisi yaitu "rantai kemiskinan hanya dapat diputus dengan pendidikan". Menurut Laksamana Sukardi (2008), kebijakan negara harus mengedepankan kesadaran pendidikan serta meningkatkan derajat kesehatan masyarakat. Kombinasi antara pendidikan dan kesehatan masyarakat adalah faktor terpenting untuk meningkatkan kesejahteraan. Sejarah telah membuktikan bahwa semua negara maju di dunia ini dibangun atas dasar kualitas sumber daya manusia. Karena sebaik apapun sistem dan regulasi tanpa pengawakan oleh sumber daya manusia yang baik akan berakhir dengan kesia-siaan. Artinya kualitas sumber daya manusia adalah kunci keberhasilan program pembangunan nasional. 
Mengurai benang kusut kemiskinan harus dimulai dari pendidikan dan kesehatan, kemudian akan berkembang menjadi bentuk "kesadaran kolektif" untuk bekerja sama antar komponen bangsa dalam suatu wadah perjuangan ekonomi guna mencapai kemakmuran bersama. Bentuk lembaga perjuangan ekonomi yang mengedepankan kerjasama atau demokrasi ekonomi adalah "Koperasi". Untuk itu sudah menjadi kewajiban pemerintah memberikan dukungan dan pendampingan serta edukasi kepada masyarakat melalui koperasi.

\section{Ekonomi Koperasi}

Ada dua pemahaman terhadap koperasi, yaitu koperasi sebagai gerakan ekonomi rakyat dan koperasi sebagai badan usaha dengan satu tujuan untuk mewujudkan masyarakat adil dan makmur berdasarkan Pancasila. Untuk itu tata kelola koperasi berdasarkan prinsip menurut Undang-Undang Perkoperasian Nomor 25 Tahun 1992: 1). Keanggotaan bersifat sukarela dan terbuka. 2). Pengelolaan dilakukan secara demokratis. 3). SHU atau Sisa Hasil Usaha dibagikan secara proporsional. 4). Kompensasi jasa terbatas pada modal. 5). Kemandirian. 6). Pendidikan dan kerjasama.

Dengan demikian jenis usaha koperasi berkaitan langsung dengan kepentingan anggota yang dapat dikualifikasikan menurut jenisnya, yaitu koperasi produsen, koperasi konsumen, koperasi simpan pinjam dan koperasi jasa.

Menurut Ropke - Phillips University Marburg Germany (2003), secara empiris potensi konflik pada koperasi berbanding lurus dengan tingkat heterogenitas anggota dan tingkat interaksi kepentingan anggota. Akumulasi dari semua potensi konflik tersebut dapat diminimalisir dengan tiga pendekatan, yaitu: 1). Tata kelola koperasi dengan mengedepankan kejujuran. 2). Transparansi manajemen. 3). Meminimize tingkat heterogenitas anggota baik pada tingkatan pendidikan dan status sosial serta pendapatan.

Dinamika tata kelola koperasi syarat dengan friksi kepentingan, untuk itu diperlukan figur pengurus yang professional, sabar dan mempunyai dedikasi serta etos kerja yang kuat guna mitigasi risiko.

Sasono (2013), hakekatnya perjuangan hidup dan kehidupan adalah memberikan manfaat bagi orang lain yang salah satu caranya adalah perjuangan ekonomi koperasi.

\section{Ekonomi Syariah}

Menurut Djamil (2005), Fikih Muamalah adalah disiplin ilmu yang mengatur kerjasama antar pihak pada aspek ekonomi dan bisnis dengan berpedoman pada Al-Qur'an dan Hadist, serta secara operasional mengedepankan empat asas perekonomian, yaitu asas suka sama suka (Q.S. 4 ayat 2), asas keadilan (Q.S. 57 ayat 25), asas menguntungkan (Q.S. 2 ayat 278-279) dan asas tolong-menolong (Q.S. 5 ayat 2).

"Hablum Minnan Nas" atau hubungan antar pihak pada kepentingan ekonomi dan bisnis termasuk aspek bermuamalah menjadi barometer kesuksesan tata kelola usaha, untuk itu ekonomi syariah pada pembahasan lebih lanjut meliputi komunikasi bisnis, syarat dan rukun akad, tata kelola organisasi bisnis, serta segala bentuk administrasi keuangan harus menjadi bahan kajian yang secara akademis menjawab tantangan bisnis di masa depan.

Menurut Al-Qosim (2009), administrasi keuangan atau tata kelola harta kekayaan pada ekonomi syariah harus diawali dari pemahaman bahwa harta kekayaan yang diperoleh atau dikuasai manusia adalah bersifat titipan dari Tuhan, sehingga cara penggunaan dan pembagian dalam tata kelola perusahaan harus sesuai dengan petunjuk Al-Qur'an yang diantaranya terdapat pada surat Al-Hasyr ayat 1-5. 
Faktor transparansi, kejujuran dan tertib administrasi keuangan sangat penting pada tahap administrasi keuangan terutama sistem akuntansi keuangan syariah, hal tersebut dimaksudkan agar para pemimpin perusahaan tidak salah dalam mengambil keputusan untuk pengembangan atau investasi perusahaan, karena laporan keuangan yang secara berkala disampaikan pada pimpinan adalah sumber informasi kondisi riil keuangan perusahaan.

\section{Pemikiran Ekonomi}

Menurut Djojohadikusumo (1994), "Cumulative Causation" adalah kecenderungan sebab akibat kumulatif yang berdampak pada perubahan titik keseimbangan atau "ekuilibrium" sebagai dampak dari lintas ekonomi internasional yang secara sepihak menguntungkan negara maju. Untuk itu sangat diperlukan pemikiran guna merespon terhadap segala bentuk perubahan atau mencari titik keseimbangan baru dengan menggunakan variabel globalisasi ekonomi dan kearifan lokal secara ekonomi yang dalam hal ini adalah ekonomi koperasi dan ekonomi syariah yang dijiwai semangat implementatif dari pasal 33 UUD 1945 dengan harapan "sintesa pemikiran" tersebut secara simultan bergerak menuju kesempurnaan konsep yang aplikatif dan membawa dampak positif untuk kesejahteraan masyarakat.

Menurut Yatim (2005), salah satu sebab kemiskinan adalah pola hidup bermewahmewah para penguasa, sehingga terjadi pemborosan keuangan negara. Tata kelola pemerintah terganggu karena kesibukan para pejabat dengan kenikmatan dunia. Untuk itu tata kelola keuangan negara harus digunakan pada sektor produktif, membuka lapangan pekerjaan, peningkatan kualitas kesehatan dan pendidikan serta terhindarkan dari praktik kecurangan dan korupsi. Dengan demikian diperlukan adanya konsep normatif yang berdasarkan atas keyakinan untuk tindakan positif yang dapat dikuantifikasikan menuju kesejahteraan umum, inilah salah satu pengertian "rasionalitas di bidang ekonomi", pemikiran tersebut berkembang menjadi "kompromi rasionalitas" menuju titik keseimbangan baru.

Korupsi dan berbagai bentuk penyimpangan penggunaan anggaran pemerintah menjadi penyebab utama tidak fokusnya program pemerintah karena terjadinya kebocoran keuangan. Untuk itu ada dua pendekatan guna meminimise praktik korupsi dan kecurangan, yaitu Pertama; adalah tindakan pencegahan dengan membangun kesadaran para pengguna anggaran dan membangun sistem keuangan yang baik sehingga menutup peluang atau kesempatan untuk korupsi, dan yang Kedua; melakukan tindakan sanksi hukum yang berat bagi pelaku kejahatan keuangan anggaran sehingga mempunyai efek jera bagi mereka yang melakukan kejahatan keuangan.

Menurut Mubyarto (1987), "Boeke" ahli ekonomi Belanda pada tahun 1910 dalam disertasinya mengatakan bahwa di Indonesia terjadi ekonomi dualistis", yaitu dua sistem ekonomi yang hidup berdampingan antara sistem kapitalis satu sisi dan pada sisi yang lain adalah sistem tradisional rakyat. Dengan demikian secara empiris akademis sistem ekonomi suatu negara dapat terjadi kombinasi antara kearifan lokal dan sistem ekonomi pasar bebas sebagai respon dari globalisasi Sila Pertama Pancasila, yaitu Ketuhanan Yang Maha Esa.

Menurut Fukuyama (2004), berbeda dengan pemikiran "Stiglitz" yang memandang proses globalisasi banyak menguntungkan negara maju dan kurang berpihak pada negara sedang berkembang. Pada sisi yang berbeda, "Francis Fukuyama "memandang Proses globalisasi banyak membawa perubahan positif pada semua negara dengan status ekonomi yang berbeda.

\section{METODE PENELITIAN}

This work is licensed under a Creative Commons Attribution-Nomercial-ShareAlike 4.0 International License. Ciptaan disebarluaskan di bawah Lisensi Creative Commons Atribusi-BerbagiSerupa 4.0 Internasional.

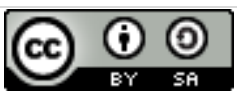


Badan ushaa dapat mengetahui kepuasan dari para konsumennya melalui umpan balik yang diberikan oleh konsumen kepada badan usaha tersebut sehingga dapat menjadi masukan bagi keperluan pengembangan dan implementasi serta peningkatan kepuasan pelanggan. Dari sini dapat diketahui pada saat pelanggan komplain. Hal ini merupakan peluang bagi badan usaha untuk dapat mengetahui kinerja dari badan usaha. Dengan adanya komplain tersebut badan usaha dapat memperbaiki dan meningkatkan layanan sehingga dapat memuaskan konsumen yang belum puas tadi. Biasanya konsumen mempunyai komitmen yang besar pada badan usaha yang menanggap kompalain darinya.

Penelitian ini membahas tentang bagaimana pelayanan Mudlarabah yang ada di Koperasi Bhakti Pertiwi Abadi Jakarta Timur, kemudian dilanjutkan dengan pemberian atribut-atribut mutu pelayanan yang diberikan penentuan atribut mutu pelayanan mengacu pada lima dimensi mutu pelayanan yang dikemukakan oleh Rangkuti (2003).

\begin{tabular}{|c|c|c|}
\hline No. & Dimensi & Atribut Pelayanan \\
\hline 1. & Reliability (keandalan) & $\begin{array}{l}\text { a. Pelayanan yang diberikan sesuai dengan prosedur } \\
\text { kebijakan yang ditetapkan. } \\
\text { b. Pelayanan yang diberikan dengan cepat. } \\
\text { c. Pelayanan yang diberikan tepat waktu. }\end{array}$ \\
\hline 2. & $\begin{array}{l}\text { Responsiveness } \\
\text { (ketanggapan) }\end{array}$ & $\begin{array}{l}\text { a. Kemudahan dalam proses pelayanan. } \\
\text { b. Petugas selalu siap melayani mitra bila dibutuhkan. }\end{array}$ \\
\hline 3. & Assurance (jaminan) & $\begin{array}{l}\text { a. Kejujuran bertransaksi. } \\
\text { b. Petugas ramah dan sopan dalam memberikan } \\
\text { pelayanan. }\end{array}$ \\
\hline 4. & Emphaty (empati) & $\begin{array}{l}\text { a. Petugas dapat berkomunikasi dengan baik dengan } \\
\text { nasabah. }\end{array}$ \\
\hline 5. & Tangible (berwujud) & $\begin{array}{l}\text { a. Kebersihan dan kenyamanan ruang kantor. } \\
\text { b. Petugas berpenampilan rapi dan bersih. } \\
\text { c. Letak kantor yang mudah dijangkau. }\end{array}$ \\
\hline
\end{tabular}

Sumber: Tjiptono, Strategi Pemasaran

Kedua belas atribut mutu pleyanan yang dianalisa merupakan hasil observasi selama beberapa minggu, yang merupakan penjabaran dari lima dimensi mutu pelayanan. Pemilihan atribut berdasarkan keinginan peneliti dan disepakati bersama dengan pihak Koperasi Bhakti Pertiwi Abadi Jakarta Timur. Tingkat kepentingan dan tingkat pelaksanaan tersebut kemudian dianalisis dengan menggunakan dua alat analisis yaitu: Analisa Importance Performance, dan Customer Satisfaction. Tingkat kepuasan merupakan fungsi dari perbedaan kinerja yang dirasakan dengan harapan yang dimiliki oleh pelanggan.

\section{Jenis Penelitian}

Jenis penelitian yang digunakan oleh penulis dalam penyusunan skripsi ini adalah studi lapangan (field research) dengan berpedoman pada sumber tertulis yang didapat dari perpustakaan. Studi ini dilakukan dengan penelitian secara langsung kepada Koperasi Bhakti Pertiwi Abadi Jakarta Timur. Data yang dibutuhkan dalam penelitian ini terdiri dari data primer dan sekunder. Data primer diperoleh melalui wawancara dengan pihak Koperasi Bhakti Pertiwi Abadi baik pimpinannya dan juga para stafnya, wawancara langsung dengan responden dan pengisian kuisoner para responden yang disini adalah para nasabah Koperasi 
Bhakti Peritwi Abadi. Sedangkan data sekunder diperoleh melalui studi literature yang berhubungan dengan penelitian, baik berupa buku yang memuat teori-teori, hasil penelitian terdahulu, pencatatan data-data yang sudah ada di badan usaha berupa laporan tahunan, sumber elektronik dari situs website, dan lain-lain.

\section{Teknik pengambilan sampel}

Pengambilan sampel dilakukan pada pelayanan Mudlarabah kepada nasabahnya dengan cara sengaja (purposive). Teknik pengambilan sampel dengan menggunakan metode non probability sampling dimana setiap anggota populasi tidak mempunyai peluang atau kemungkinan yang sama untuk terpilih menjadi sampel (Tanjung, 2010). Sedangkan jenis non probability sampling yang digunakan adalah quota sampling. Dengan alasan untuk memperoleh sejumlah nasabah dari berbagai umur dari yang muda hingga yang tua. Sehingga diharapkan penarikan sampel dengan metode ini dapat mewakili populasi yang sebenarnya.

Menurut Durianto (2004), quota sampling dapat dikatakan juga sebagai judgement sampling dua tahap. Tahap pertama, merumuskan kategori kontrol (kuota) dari populasi yang diteliti berdasarkan pengelompokan umur (muda, sedang, tua) yang terdefinisikan sebagai basis dari keputusan pemilihan sampel. Tahap kedua, penentuan sampel yang akan dambil secara judgement yaitu penarikan sampel berdasarkan ketidaksibukan nasabah setelah nasabah melakukan transaksi di Koperasi setempat atau dating langsung ke tempat tinggal nasabah untuk memperoleh data yang lebih akurat dan dalam. Jumlah sampel nasabah yand dipilih dari populasi yang diteliti digunakan dengan metode Slovin (Umar, 2003) dengan rumus sebagai berikut:

Gambar Metode Slovin

dimana:

$$
\pi=\frac{N}{1+N(e)^{2}}
$$

$\pi=$ Ukuran sampel

$\mathrm{N}=$ Ukuran populasi

$e \quad=$ Kesalahan pengambilan sampel ditetapkan $10 \%$

Dari data bulan Mei populasi Koperasi Bhakti Pertiwi Abadi Jakarta Timur yang aktif sebesar 367 orang. Ukuran sampel yang diambil pada penelitian ini dengan menggunakan rumus Slovin sebesar:

$$
\pi=\frac{367}{1+367(0,1)^{2}}=0,9997
$$

Namun melihat banyak pertimbangan dengan sedikitnya jumlah keseluruhan yang memakan pelayanan mudlarabah maka hasil dari penarikan sampel bisa diambil setengahnya yaitu 50 responden yang seharusnya adalah pengambilan sampel sebanyak 100 responden. Ini semua berdasarkan pada salah satu metode penarikan sampel yaitu $(n+1)$ sehingga penulis mengambil sampel sebanyak 50 responden.

\section{Teknik pengumpulan data}

Teknik pengumpulan data dilakukan dengan teknik wawancara kepada pihak Koperasi Bhakti Pertiwi Abadi Jakarta Timur guna mengetahui produk yang ada. Dan memberikan kuisoner kepada nasabah Koperasi Bhakti Pertiwi Abadi yang terpilih. Kuisoner penelitian terdiri dari pertanyaan terbuka dan tertutup. Kuisoner diperlukan untuk mengetahui sejauh 
mana tingkat kepuasan nasabah Koperasi Bhakti Pertiwi Abadi terhadap pelayanan Mudlarabah.

\section{Pengolahan data dan Analisa data}

Pengolahan data dan analisis dalam penelitian yang dilakukan ini menggunakan bantuan program software Microsoft Excel 2016 dan SPSS for Windows versi 27. Data dianalisis secara deskriptif untuk karakteristik konsumen. Untuk menganalisa atribut-atribut yang dianggap penting dan menganalisa kinerja dalan pencapaian kepuasan nasabah Koperasi Bhakti Pertiwi Abadi Jakarta Timur digunakan Important Performance Analysis. Sedangkan, untuk mengukur tingkat kepuasan nasabah terhadap seluruh atribut menggunakan analisis Customer Satisfaction Index.

\section{Uji validitas dan reabilitas}

Kuisioner yang diberikan dan dikumpulkan pada penelitian ini diuji dengan validitas. Pengujian validitas dimaksudkan untuk mengetahui sejauh mana suatu alat pengukur (instrument) mengukur apa yang ingin diukur. Jika alat ukur yang dinyatakan benar, selanjutnya alat ukur tersebut di uji reabilitas (keandalan). Rehabilitas adalah suatu nilai yang menunjukkan konsistensi suatu alat ukur dalam mengukur gejala yang sama (Umar, 2003). Rehabilitas alat ukur dalam bentuk skala dapat dicari menggunakan metode Cronbach, dengan rumus sebagai berikut:

$$
\begin{aligned}
& \text { Gambar Metode Cronbach } \\
& r x y=\frac{n X Y}{n X^{2-(?)^{2}}} \frac{X Y}{Y^{2}-(?)^{2}}
\end{aligned}
$$

dimana:

$r x y=$ korelasi antasa $\mathrm{X}$ dan $\mathrm{Y}$

$n=$ jumlah responden

$\mathrm{X}=$ skor masing-masing pertanyaan

$\mathrm{Y}=$ skor total

Jika nilai $\mathrm{r}$ dihitung lebih besar dari nilai $\mathrm{R}$ tabel maka sahih dan semakin saling mendekati 1,00. Uji validitas dilakukan pada 50 responden dengan toleransi 5 persen. Pengujian validitas diolah dengan menggunakan software Microsoft Excel 2016. Selanjutnya alat ukur tersebut diuji rehabilitas (keandalan). Stabilitas adalah suatu nilai ujian menunjukkan konsistensi suatu alat ukur di dalam mengukur gejala yang sama (Umar, 2003). Realibilitas alat ukur dalam bentuk skala dicari dengan menggunakan teknik alpha cronbach, dengan rumus sebagai berikut:

$$
\begin{aligned}
& \text { Gambar Teknik Alpha Cronbach } \\
& r^{11} \frac{k}{k-1} 1-\frac{a^{2}}{a t^{2}}
\end{aligned}
$$

dimana:

$r^{11}=$ Reliabilitas instrument

$k=$ Banyaknya butir pertanyaan

$a^{2}=$ Jumlah ragam butir

$a t^{2}=$ Jumlah ragam total 


\section{HASIL PENELITIAN DAN PEMBAHASAN}

\section{Hasil Penelitian}

Penyebaran kuesioner dalam penelitian ini dilakukan terhadap 50 nasabah Koperasi Bhakti Pertiwi Abadi. Dan hasil survei menunjukkan bahwa mayoritas responden berjenis kelamin laki-laki 28 persen dan perempuan 72 persen. Hal ini dikarenakan pembiayaan dipakai untuk menambah modal usaha bagi para perempuan yang sudah memiliki usaha.

\section{Pembahasan}

\section{Impartant Performance Analysis}

Setelah meneliti atribut-atribut penentu kepuasan, selanjutnya akan diperlihatkan rataan keseluruhan berdasarkan tingkat kepentingan dari nasabah Koperasi Bhakti Pertiwi Abadi. Penilaian terhadap tingkat kepentingan menunjukkan harapan nasabah. Total nilai rataan tingkat harapan yang digunakan adalah 3,64 berdasarkan atas seluruh nilai tingkat harapan nasabah koperasi dalam hal itu dapat dilihat di tabel berikut.

Tabel 1: Rataan Tingkat Harapan

\begin{tabular}{clcc}
\hline No Atribut & \multicolumn{1}{c}{ Atribut } & Total Bobot & Rataan \\
\hline 1 & Lokasi koperasi & 205 & 4,10 \\
2 & Kemudahan transaksi & 212 & 4,24 \\
3 & Kecepatan transaksi & 215 & 4,30 \\
4 & Ketelitian administrasi & 212 & 4,24 \\
5 & Fasilitas & 210 & 4,20 \\
6 & Multiguna produk & 193 & 3,86 \\
7 & Besar pembiayaan & 204 & 4,08 \\
8 & Besar setoran & 194 & 3,88 \\
9 & Bagi hasil & 216 & 4,32 \\
10 & Promosi & 202 & 4,04 \\
11 & Antrian & 191 & 3,82 \\
12 & Kesigapan karyawan & 214 & 4,28 \\
13 & Ketanggapan & 227 & 4,54 \\
14 & Keamanan & 228 & 4,56 \\
\hline & Total & & $\mathbf{5 8 , 4 6}$ \\
\cline { 2 - 4 }
\end{tabular}

Untuk mengetahui hasil rataan yang dari tingkat harapan nasabah kopperasi tersebut maka dapat melihat pada rumus berikut:

Rataan $=\frac{\Sigma X}{n}$

dimana:

$X=$ Jumlah rataan dari tiap total bobot

$n$ = Jumlah atribut dalam pengambilan sampel

Berdasarkan tabel 1, maka dapat diketahui bahwa sistem keamanan nasabah dianggap paling penting oleh para koperasi BPA dengan nilai 4,56. Karena bagi para nasabah 
keamanan negara bagian terpenting dalam pembiayaan Mudlarabah. Sedangkan sistem antrian merupakan harapan nasabah paling kecil dengan nilai 3,82.

Berikutnya akan disajikan nilai rataan terhadap tingkat kinerja Koperasi Bhakti Pertiwi Abadi yang sudah dilakukan kepada nasabahnya. Total rataan hasil penelitian yang dilakukan kepada nasabah mendapatkan hasil dari sinergi koperasi adalah 3,36. Penilaian ini berdasarkan tingkat kinerja yang dirasakan oleh nasabah Koperasi Bhakti Pertiwi Abadi dan dapat dilihat pada tabel di bawah ini. Dari hasil yang didapatkan maka total rataan tingkat kinerja yang telah dilakukan oleh koperasi dan dirasakan oleh nasabah adalah 3,36 dan bagi para nasabah mereka sudah mendapatkan kepuasan dari hasil kinerja koperasi yang mereka rasakan.

Tabel 2: Rataan Tingkat Kerja

\begin{tabular}{clcc}
\hline No Atribut & \multicolumn{1}{c}{ Atribut } & Total Bobot & Rataan \\
\hline 1 & Lokasi koperasi & 157 & 3,14 \\
2 & Kemudahan transaksi & 169 & 3,38 \\
3 & Kecepatan transaksi & 155 & 3,14 \\
4 & Ketelitian administrasi & 178 & 3,56 \\
5 & Fasilitas & 171 & 3,42 \\
6 & Multiguna produk & 153 & 3,06 \\
7 & Besar pembiayaan & 172 & 3,44 \\
8 & Besar setoran & 169 & 3,38 \\
9 & Bagi hasil & 174 & 3,48 \\
10 & Promosi & 162 & 3,24 \\
11 & Antrian & 125 & 2,50 \\
12 & Kesigapan karyawan & 184 & 3,68 \\
13 & Ketanggapan & 177 & 3,54 \\
14 & Keamanan & 202 & 4,04 \\
\hline & Total & & $\mathbf{4 7}$ \\
\cline { 2 - 4 }
\end{tabular}

Dari tabel 2, dapat diketahui bahwa atribut keamanan di koperasi Koperasi Bhakti Pertiwi Abadi memiliki skor paling tinggi yaitu 4,04. Sementara itu, sistem antrian memiliki tingkat kinerja paling rendah dengan nilai 2,50. Atribut ini harus menjadi prioritas untuk memperbaiki kinerja Koperasi Bhakti Pertiwi Abadi dalam melayani para nasabahnya. Selanjutnya untuk mengetahui posisi masing-masing atribut yang diperoleh berdasarkan skor tingkat kepentingan dan tingkat kinerja, dilakukan dengan pemetaan ke dalam diagram kartesius. Dari hasil penilaian yang dilakukan oleh nasabah Koperasi Bhakti Pertiwi Abadi terhadap kinerja Koperasi Bhakti Pertiwi Abadi dapat dikatakan tingkat kepuasan nasabah secara keseluruhan terhadap pelayanan pembiayaan Mudlarabah di Koperasi Bhakti Pertiwi Abadi adalah puas.

Hal ini dapat dilihat dari nilai CSI 66 persen $(0,66)$ yang artinya tingkat kepuasan total terletak antara nilai 0,66-0,80 telah menunjukan kepuasan nasabah terhadap pelayanan Mudlarabah di Koperasi Bhakti Pertiwi Abadi adalah puas. 
Tabel 3: Perhitungan Customer Satifaction Index

\begin{tabular}{clcccc}
\hline $\begin{array}{c}\text { No } \\
\text { Atribut }\end{array}$ & \multicolumn{1}{c}{ Atribut } & $\begin{array}{c}\text { Rataan } \\
\text { Harapan }\end{array}$ & $\begin{array}{c}\text { Faktor } \\
\text { Kepentingan } \\
\text { Berbobot (\%) } \\
\mathbf{( a )}\end{array}$ & $\begin{array}{c}\text { Rataan } \\
\text { Kinerja } \\
\text { (b) }\end{array}$ & $\begin{array}{c}\text { Skor } \\
\text { Berbobot } \\
\text { C=(axb) }\end{array}$ \\
\hline 1 & Lokasi koperasi & 4,10 & $7,07 \%$ & 3,14 & 0,22 \\
2 & Kemudahan transaksi & 4,24 & $7,25 \%$ & 3,38 & 0,24 \\
3 & Kecepatan transaksi & 4,30 & $7,35 \%$ & 3,14 & 0,23 \\
4 & Ketelitian administrasi & 4,24 & $7,25 \%$ & 3,56 & 0,25 \\
5 & Fasilitas & 4,20 & $7,18 \%$ & 3,42 & 0,24 \\
6 & Multiguna produk & 3,86 & $6,60 \%$ & 3,06 & 0,20 \\
7 & Besar pembiayaan & 4,08 & $6,97 \%$ & 3,44 & 0,23 \\
8 & Besar setoran & 3,88 & $6,63 \%$ & 3,38 & 0,22 \\
9 & Bagi hasil & 4,32 & $7,38 \%$ & 3,48 & 0,25 \\
10 & Promosi & 4,04 & $6,91 \%$ & 3,24 & 0,22 \\
11 & Antrian & 3,82 & $6,53 \%$ & 2,50 & 0,16 \\
12 & Kesigapan karyawan & 4,28 & $7,32 \%$ & 3,68 & 0,26 \\
13 & Ketanggapan & 4,54 & $7,76 \%$ & 3,54 & 0,27 \\
14 & Keamanan & 4,56 & $7,80 \%$ & 4,04 & 0,31 \\
\hline Total & & $\mathbf{5 8 , 4 6}$ & $\mathbf{1 0 0 \%}$ & $\mathbf{4 7}$ & \\
\hline Total berbobot & \multicolumn{5}{|c}{} \\
\hline Indeks kepuasan &
\end{tabular}

Koperasi Bhakti Pertiwi Abadi telah berhasil memberikan pelayanan Mudlarabah yang bermutu, sesuai dengan tingkat harapan yang diinginkan nasabahnya. Meskipun demikian Koperasi Bhakti Pertiwi Abadi terus berusaha untuk berkomitmen guna meningkatkan pelayanan terhadap nasabahnya pada tahun-tahun yang akan datang. CSI tersebut dapat digunakan oleh Koperasi Bhakti Pertiwi Abadi untuk menjadi acuan dalam menentukan sasaran peningkatan kepuasan nasabahnya di masa datang.

$$
\begin{aligned}
\text { Total Indeks Kepuasan Nasabah } & =(\text { Total WS : Skala Maksimum) x } 100 \% \\
& =(3,3: 5) \times 100 \% \\
& =66 \%
\end{aligned}
$$

Dari tabel 3, dapat diketahui bahwa indeks kepuasan kepuasan nasabah terhadap pelayanan pembiayaan Mudlarabah Koperasi Bhakti Pertiwi Abadi adalah 66 persen. Hal ini menunjukan bahwa tingkat kepuasan nasabah pembiayaan Mudlarabah Koperasi Bhakti Pertiwi Abadi secara umum dan keseluruhan berada pada kategori puas. Sehingga, kinerja Koperasi Bhakti Pertiwi Abadi dinilai sangat baik karena mampu menjaga kepercayaan terhadap nasabahnya. Oleh karena itu kinerja yang sudah berjalan sekarang harus tetap dipertahankan atau bahkan lebih ditingkat lagi.

\section{KESIMPULAN DAN SARAN}

\section{Kesimpulan}

This work is licensed under a Creative Commons Attribution-Nomercial-ShareAlike 4.0 International License. Ciptaan disebarluaskan di bawah Lisensi Creative Commons Atribusi-BerbagiSerupa 4.0 Internasional.

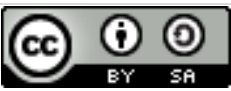


Berrdasarkan hasil penelitian dan pembahasan, kesimpulan dalam penelitian ini adalah sebagai berikut: 1) Tujuan mengajukan pembiayaan Mudlarabah dari penelitian responden adalah untuk menambah dan ini sebagian besar dari nasabah koperasi bhakti pertiwi abadi adalah menjawab itu. Dengan kemudahan yang koperasi berikan dalam mengajukan pembiayaan Mudlarabah itu maka para nasabahnya akan menunjukan kepada para keluarga, teman dan rekan lainnya apabila membutuhkan dana yang mudah dengan sistem bagi hasil proporsional maka mereka yaitu para nasabah akan menunjukan bahwa koperasi merupakan tempat yang paling tepat. 2) Sedangkan dari sisi kinerja yang telah dilakukan oleh Koperasi Bhakti Pertiwi Abadi terhadap nasabahnya yang paling dirasakan memiliki tingkat kepuasan nasabah adalah keamanan dalam menghadapi keluhan nasabah dengan memiliki rataan skor nilai 4,04 sedangkan tingkat kinerja yang dirasakan paling kecil adalah multiguna yang mimiliki nilai rataan skor 3,06. 3) Costumer Satisfaction Index (CSI) untuk atribut mutu jasa pelayanan terhadap pembiayaan mdhurabah di koperasi bhakti pertiwi abadi adalah $66,0 \%$ atau 0,66. Hal ini menunjukkan bahwa tingkat kepuasan mitra terletak antara nilai 0,66 0,80 telah menunjukan kepuasan nasabah terhadap pelayanan Mudlarabah di koperasi bhakti pertiwi abadi adalah puas.

\section{Saran}

Saran dalam penelitian ini yang mungkin dapat dijadikan sebagai bahan pertimbangan adalah sebagai berikut: 1) Melihat hasil yang ada maka atribut yang harus mendapatkan prioritas utama dari Koperasi Bhakti Pertiwi Abadi adalah keamanan karena ini merupakan tingkat kinerja tertinggi sedangkan harapan nasabah yang paling diinginkan bagi mereka adalah sistem keamanan. Oleh karena itu pihak koperasi harus meningkatkan kinerja dalam sistem keamanannya. 2) Mempertahankan pelayanan yang ada karena para nasabah sudah merasakan kepuasan pelayanan dalam pembiayaan Mudlarabah di koperasi bhakti pertiwi abadai serta meningkatkan mutu pelayanan dan menggalang komitmen dari seluruh kartawan atau petugas (SDM) agar memenuhi kepuasan nasabahnya sehingga menciptakan loyalitas nasabah itu sendiri.

\section{DAFTAR PUSTAKA}

Al-Qur'an dan Terjemahnya, Departemen Agama Republik Indonesia

Al-Qosim, Abu 'Ubaid. (2009). Al-Amwal - Ensiklopedia Keuangan Publik. Jakarta. Gema Insani.

Arep, Ishak dan Hendri, Tanjung (2003). Manajemen Sumber Daya Manusia. Jakarta: Universitas Trisakti

Azra, Azyumardi. (2005). Dari Harvard Hingga Makkah. Jakarta. Republika.

Djamil, Fathurrahman. (2005). Fikih Muamalah, pada buku Ensiklopedi Tematis Dunia Islam. Jakarta. PT. Ichtiar Baru, Van Hoeve.

Djojohadikusumo, Sumitro. (1994). Perkembangan Pemikiran Dasar Teori Ekonomi Pertumbuhan dan Ekonomi Pembangunan. Jakarta. PT. Pustaka LP3ES.

Durianto, D., Sugiarto, \& Sitinjak, T. (2004). Strategi Menaklukkan Pasar Melalui Riset Ekuitas dan Perilaku Merek. Jakarta: PT. Gramedia Pustaka Utama

Fukuyama, Francis. (2004). The End of History and Tha Last Man - Kemenangan Kapitalisme dan Demokrasi Liberal. Yogyakarta. CV. Qalam.

Umar, Husein. (2003). Metode Riset Perilaku Konsumen Jasa. Jakarta: Ghalia Indonesia.

Mubyarto. (1987). Ekonomi Pancasila - Gagasan dan Kemungkinan. Jakarta. LP3ES. 
Ropke, Jochen - Phillips University Marburg Germany. (2003). Ekonomi Koperasi - Teori dan Manajemen. Jakarta. Salemba Empat.

Rangkuti, Freddy. (2003). Analisis SWOT Teknik Membedah Kasus Bisnis. Jakarta. Gramedia Pustaka Utama

Stiglitz, Joseph E. (2007). Making Globalization Work - Menyiasati Globalisasi Menuju Dunia Yang Lebih Adil. Bandung. PT. Mizan Pustaka.

Sukardi, Laksamana. (2008). Memberantas Kemiskinan Melawan Gombalisasi Global. Jakarta. PDP.

Undang-Undang Perkoperasian Nomor 25 Tahun 1992.

Yatim, Badri. (2005). Sejarah Peradaban Islam. Jakarta. PT. Raja Grafindo Persada. 